\title{
Debt and Destruction: The Global Abuse of Haiti and Unbalancing the Myth of Benevolent Canada
}

Sabrina Uwase

An integral responsibility of nation-states is to provide protection and the means for attaining a fulfilling life to those it governs. Given the fact that most current global powers were not founded with the needs of racialized peoples in mind, one is infuriated but not surprised, at the cyclical pattern of disregard and exploitation that people of colour in the Americas experience. Indigenous and Black communities in the Americas are not just disregarded by the state, but are actively targeted for exploitation and undermining. Analyzing Haiti's post-colonial history and Canada's domestic and international mining operations, I argue that nations in the Caribbean and Latin America have been extensively exploited economically by imperial powers, and their survival undermined by colonial legacies. Numerous countries in the region, to varying degrees, continue to experience the wrath of state-sponsored white supremacy and crippling debt that prevent authentic development. I advance the position that coerced debt and resource extraction have been weaponized against already ostracized communities by behemoth states that employ the myth of being a post-racial democracy. This paper also highlights a complex set of global relationships by linking extraction, state-corporate relations, and North-South divides, with a focus on Canadian mining in Latin America.

When revolutions are discussed, people are often familiar only with the American, French, or Russian ones. In efforts to make the incredible feat of the Haitian Revolution an exception and not the norm, the nation has been physically, politically, and economically violated by imperial powers. This whitewashing of history leaves little room for the acknowledgement and celebration of non-white actors having a claim to what counts as important. From its inception, Haiti has been the source of inspiration for various slave rebellions while simultaneously sparking the first embers for the global fight for Black liberation. Two years prior to the beginning of the Haitian Revolution, France published its Declaration of the Rights of Man and Citizen in 1789. Although considered forward thinking for the period, contemporary readers will note that it only applied to white property-owning men. Nevertheless, the notion that all men were born "free and equal in rights" would go on to inspire oppressed peoples in Haiti to claim it.

Despite Haiti appearing to be self-governing on paper, there exist external actors who exert considerable power over the state, undermining its sovereignty. I maintain that Haiti has not fully decolonized itself from the economic and political control of current imperial powers like the US and Canada. For several decades after Haiti had fought for its independence, world powers refused to officially recognize it as a sovereign state (Trouillot 47). While most other nations are applauded for gaining their independence, Haiti was largely punished by both Europe and its immediate neighbors in the region. Examples of this include the US cutting diplomatic ties after its independence, the prevention of Haitians leaving the island in efforts to stop the exportation of radical thought, and the numerous economic embargoes that were overwhelming for the newly founded republic (Fuertes 296). In an action that one can only describe as economic terrorism, France pressured Haiti into agreeing to pay 150 million francs in 1825, as retribution for the "loss" of French interests in exchange for recognizing their independence (Fuertes 296). In 1838, France decreased the debt to 90 million francs. With current inflation accounted for, 90 million francs today is upwards of 21 billion US dollars that Haiti had to pay for debt that can be reasonably 
regarded as illegitimate (Sommers 2015). Haiti being barred from engaging in regional economic trade while being expected to repay such a ludicrous debt is a mindboggling situation. It was in this period that Haiti's independence was used against it to continue the long history of financial exploitation on the island by imperial powers.

The informal recolonization of Haiti has largely been made possible by debt, "aid," and North American foreign policy. The US historically did not recognize Haiti's independence for decades and currently does not seem to respect its legitimacy as a self-governing state. Even before the birth of Haiti as a free republic, US President Andrew Johnson had hopes of seizing the whole island (Hidalgo 56). Soon after, in 1910, US President William Taft provided Haiti with an interest-heavy loan to help pay its debt (U.S. Department of State). Failure to repay this new debt in 1914, led to the US moving much of Haiti's money to the US with the rationale of "stabilizing" Haiti's economy (U.S. Department of State). When Haitians understandably expressed disdain for their suffering through demonstrations, the US responded by occupying the nation for 19 years (Scott 35). The US has coached and selected numerous Haitian leaders, and exiled those who fail to advance its agenda. It is difficult for many to make sense of the turmoil in Haiti because the detriment has been very incremental. Constant intervention and external meddling in Haiti have robbed the nation and its people the right to self-govern. Wealth, whether through resource extraction or labour, continues to be endlessly depleted from Haiti, to benefit the insatiable hunger of Global North countries.

The blatant mistreatment of underprivileged nations has transformed into the more insidious practice of "spreading democracy" or encouraging "economic development." Explicit enslavement has been substituted with a combination of the following: exploitation of a cheap labour force, implementation of regimes or leaders loyal to imperial interest, and interest-heavy conditional loans. Debt has been primarily used for the underdevelopment of already struggling economies for the benefit of behemoth states like the US. The Caribbean and Latin America have both been imperilled by financial colonialism - primarily through high-interest conditional loans. Currently, one could make the claim that not one nation in the Caribbean has complete economic autonomy. As Norman Girvan once said, nations in the Caribbean are "in-dependence" rather than independent (Girvan 22). "In-dependence." meaning that the success or failure of Caribbean political economies is closely linked to the foreign policy goals of global powers. It can be argued that colonial patterns of trade are still being utilized in Haiti at present. Former plantation-based economies, which account for much of the Caribbean, have been strong-armed into continuing the pattern of basing much of their economy on natural resource extraction. With little diversification of their economies, Caribbean nations fall into the colonial tradition of capital being too concentrated in one sector, which leads to unequal structures in a nation's economy (Myint 318).

Contrary to popular belief, the primary goal of developmental theories and models produced by Western states is not to alleviate poverty but to provide large economies access to vulnerable markets. Despite global financial organizations like the World Bank and International Monetary Fund striving to appear independent on paper, they implicitly and explicitly advance the foreign policy goals of established economies - primarily those of the United States, Canada, and European states. Many developmental theories can be described as removed because they do not adequately acknowledge the colonial histories that funded the development of numerous global powers at the expense of racialized peoples (Vanden 157). Numerous states that are categorized as underdeveloped have been deprived of a clean slate that independence promises, due to the entrenchment of colonial legacies within cornerstone institutions. Colonial legacies have made 
their presence known primarily through socio-economic and political barriers that benefit former colonial and current imperial powers. Since first encounter, the Caribbean and Latin America have largely been viewed by colonizers and white settlers alike as a place to endlessly exploit for capital, regardless of social suffering or environmental consequences.

Especially in the Latin America, there exist a widely-employed myth that extraction will advance the economic development of resource-rich impoverished nations (Burchart 469). Within much of the scholarship linking extraction with development, there seems to be a dangerous silence regarding the gross human suffering and environmental destruction that is caused in the hamsterwheel pursuit of development. I maintain that the widespread existence of neoliberal market policies in the Caribbean and Latin America should be described as economic terrorism. In efforts to prevent market crashes concocted by imperial powers, nations in the region are coerced into accepting interest-heavy loans that are extremely difficult for nations already in debt to repay. To make matters worse, conditional loans usually require nations to reduce public spending and privatize pillar institutions like education, healthcare, and electricity, which devastate working class people (Easterly 4).

In efforts to acknowledge that the governments and people who are most affected have a degree of self-determination, one must interrogate the part that Caribbean and Latin American actors play in facilitating foreign exploitation. I maintain that these countries are not actively welcoming foreign intervention, but instead are strong-armed into implementing neoliberal economic policies that have social and environmental consequences. Using the pretext of development, leaders in Latin America have often argued that extractive projects are necessary to fund the well-being of society. Using the former to justify the latter, corporations and state actors use the pursuit of development to advance particular interests that devastate the most defenceless members of the societies affected. This trading-in of environmental protection and the well-being of people for the pursuit of wealth is labelled by Peter Dauvergne as "shadows of consumption." In his description of "shadows of consumption," Dauvergne emphasizes the overlooked and concealed dangers of excessive extraction and its effects on people, wildlife, and the environment (Dauvergne 3).

Nations and multibillion-dollar conglomerates can be described to be working together to gain highly profitable extractive contracts. A fact that surprises many is that Canada is one of the largest mining countries in the world. Outside of continental North America, much of Canada's mining is done in numerous Latin American countries (Gordon 278). One could describe Canada's state-corporate interests in Latin America as economic colonialism. Barrick Gold, founded by Peter Munk, is continuously regarded as the leader in gold mining. The list of environmental, sexual, and labour violations done in efforts to increase Barrick Gold's profits is ever-growing (Holterman 60). Munk's humanitarian legacy has been bought and paid for with stolen wealth. Munk's donations cannot be removed from their roots in Indigenous land dispossession, labour exploitation, sexual violence, and environmental violence. The propaganda-like optics of Canada being portrayed as gentle and benevolent is extremely dangerous because it conceals and excuses state-sponsored violence as exceptionalities instead of the norm that it is.

Coining the term "present absence," Andrea Smith advances the view that there is a historical and contemporary erasure of Indigenous peoples and cultures from North American public discourse (70). Indigenous communities in Canada have not only experienced genocide and subjugation by white settlers historically, but continue to resist attacks against their histories, land, 
languages, and culture. Ann Stoler writes that "racism does not merely arise in moments of crisis, in sporadic cleansings. It is internal to the biopolitical state, woven into the web of the social body, threaded through its fabric" (Stoler 172). With former Prime Minster Stephen Harper's apology for Canadian residential schools in 2006 and the creation of the Truth and Reconciliation Commission one cannot help but skeptically question whether these steps have been taken genuinely or for optics' sake. Apologies should not be considered an exoneration of Canada's past crimes, because the state continues to engage in policies and business ventures that disregard and harm Indigenous communities both at home and abroad. The myth of a utopian and multicultural society in Canada drives the state further into neoliberal territory. This endorses a narrative of acceptance, thus undermining local and national pressures to tackle our colonial history and present.

The irony is not lost on some that Canada and the US claim to be beacons for freedom and democracy yet infringe on the right for sovereign nations to self-govern without external influence. Haiti was the first blow in breaking the chain of the enslavement of Black people. This reorganizing of the status quo was detrimental to economies that were heavily dependent on enslaved labour. Because of this, imperial powers tried profusely to destabilize the first Black Republic to deter others from pursuing the same means. Haiti's initial independence showed that physical decolonization was a possibility. Primarily through debt and resource extraction, imperial nations have succeeded in economically colonizing politically independent states in the Caribbean and Latin America. 


\section{Works Cited}

Burchardt, Hans-Jürgen, and Kristina Dietz. "(Neo-) Extractivism-A New Challenge for Development Theory from Latin America." Third World Quarterly 35, no. 3, 2014, p. 469.

Dauvergne, Peter. "Introduction: The Ecological Shadows of Rising Consumption. Chapter 2: Dying of Consumption." The Shadows of Consumption: Consequences for the Global Environment, MIT Press. 2010. pp. 1-32.

Easterly, William. "What Did Structural Adjustment Adjust?: The Association of Policies and Growth with Repeated IMF and World Bank Adjustment Loans." Journal of Development Economics 76, no. 1, 2005, pp. 1-22.

Fuertes, Digna Castañeda. "The Haitian Revolution: Legacy and Actuality." International Journal of Cuban Studies. 2010. p. 296.

Gordon, Todd and Jeffrey R. Webber. Blood of Extraction: Canadian Imperialism in Latin America. Fernwood Publishing, 2016. p. 278.

Hidalgo, Dennis. "Charles Sumner and the Annexation of the Dominican Republic." Itinerario 21, no. 2, 1997. p. 56.

Holterman, Devin. "Slow Violence, Extraction and Human Rights Defence in Tanzania: Notes from the field." Resources Policy 40, 2014, pp. 59-65.

Myint, Hla. "The "classical theory" of international trade and the underdeveloped countries." The Economic Journal 68, no. 270, 1958, p. 318.

Scott, Helen. "200 years of US Imperialism: Haiti Under Siege." International Socialist Review 35, 2004.

Smith, Andrea. "Not an Indian Tradition: The Sexual Colonization of Indigenous Peoples". Hypatia, v. 18. i. 2, 2003, pp. 70-85.

Sommers, Jeffrey. Race, Reality, and Realpolitik: U.S.-Haiti Relations in the Lead Up to the 1915 Occupation. 2015. p. 124.

Stoler, Ann. Race and the Education of Desire. Duke University Press, 1997, p. 172.

Trouillot, Michel-Rolph. "Haiti's Nightmare and the Lessons of History." NACLA Report on the Americas 27, no. 4, 1994, pp. 46-51.

U.S. Government. "U.S. Invasion and Occupation of Haiti, 1915-34." U.S. Department of State. Accessed March 8, 2019. https://2001-2009.state.gov/r/pa/ho/time/wwi/88275.htm.

Vanden, Harry E. and Gary Prevost. "The Political Economy of Latin America" in, Politics of Latin America: The Power Game (Sixth Ed). 2017, pp. 157-191. 
Sabrina Uwase

Debt and Destruction

Weyland, Kurt. 2002. The Politics of Market Reform in Fragile Democracies: Argentina, Brazil, Peru, and Venezuela. Princeton University Press, 2002. 